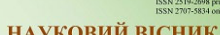

Whesessenger of Lviv National University of

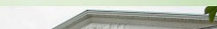

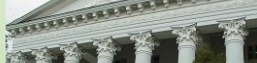

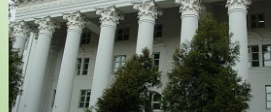

СЕРЯ "СЛЬСБКОГОСПОДАРСЬК НАУК"

(3)

2021
Науковий вісник Яьвівського національного університету ветеринарної медицини та біотехнодогій імені С.3. Гжицького. Серія: Сільськогосподарські науки

\section{Scientific Messenger of Lviv National University of Veterinary Medicine and Biotechnologies. Series: Agricultural sciences}

UDC 637.2.053.054

\title{
Quality control of butter
}

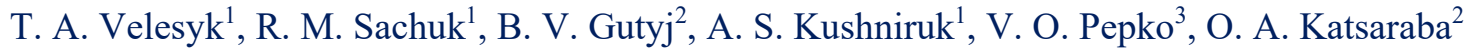 \\ ${ }^{1}$ Rivne State University for the Humanities, Rivne, Ukraine \\ ${ }^{2}$ Stepan Gzhytskyi National University of Veterinary Medicine and Biotechnologies Lviv, Ukraine \\ ${ }^{3}$ Ternopil Research Station, Institute of Veterinary Medicine, NAAN, Ternopil, Ukraine
}

Article info

Received 31.05.2021

Received in revised form 30.06.2021

Accepted 01.07.2021

Rivne State University for the Humanities, Plastova Str., 29-a, Rivne, 33028, Ukraine.

Tel.: +38-097-671-90-63

E-mail: sachuk.08@ukr.net

Stepan Gzhytskyi National University of Veterinary Medicine and Biotechnologies Lviv, Pekarska Str., 50, Lviv,

79010, Ukraine

Ternopil Research Station Institute of Veterinary Medicine NAAN, str. Troleybusna, 12, Ternopil, 46027, Ukraine.
Velesyk, T. A., Sachuk, R. M., Gutyj, B. V., Kushniruk, A. S., Pepko, V. O., \& Katsaraba, O. A. (2021). Quality control of butter. Scientific Messenger of Lviv National University of Veterinary Medicine and Biotechnologies. Series: Agricultural sciences, 23(95), 114-121. doi: 10.32718/nvlveta9517

The most common problem among ready-made foods is the adulteration of butter, which is replaced by margarine or vegetable spreads. Milk and other dairy products made from raw milk are not left out. The production and sale of low-quality, counterfeit products poses a direct threat to human health and affects the competitive environment among producers. As a result of research, it should be noted that the raw milk market is not fully saturated, so improving the quality of cream production and processing of milk products, namely butter, competition for suppliers, microbiological improvements, as well as improvements to plants and systems - remains relevant. During the analysis, some physicochemical parameters of butter were studied, namely: acidity of the fat phase, mass fraction of moisture and fat. The acidity index was within the norm, although it differed in all samples: the lowest was found in sample № $1\left(1.1^{\circ} \mathrm{K}\right)$, and the highest was in sample № $2\left(1.6^{\circ} \mathrm{K}\right)$. As for such an indicator as the content of table salt and the content of fat and $\mathrm{pH}$ of plasma, the oils Sweet cream "Selyanske", 72,6\% TM "Svoya Liniya", Sweet cream, $73.0 \%$ LLC "Eney", "Poltavske", $62.5 \%$ LLC "Techmolprom" do not meet the requirements of DSTU 4399:2005. The mass fraction of fat in butter brands PJSC "Dubnomoloko" and "Pryvat-Fud" - was lower than indicated on the package, by $1.4 \%$ and $2.6 \%$, respectively, and brands "Svoya Liniya", LLC "Eney" and Techmolprom LLC on the contrary - by $18.0 \%, 18.4 \%$ and $12.5 \%$ more. According to the results of microbiological studies, it was found that the number of mesophilic aerobic and facultatively anaerobic microorganisms, yeasts, fungi and bacteria of the Escherichia coli group in the studied samples of butter of all brands does not exceed the permissible norms. This fact testifies to the relative "purity" of the raw material from which the butter was made, as well as to the observance of veterinary and sanitary and hygienic norms during the production and storage of butter. Summing up the research, it should be noted that, despite the identified physical and chemical shortcomings of all samples of butter, preference should be given to sour cream butter "Selyanske", $73.0 \%$ of PJSC "Dubnomoloko" and "Selyanske" sweet cream, $73.0 \%$ "Privat- Fud", as none of them exceeded such indicators as fat content and plasma $\mathrm{pH}$ of oil, which may indicate the $a b$ sence of impurities in vegetable fats in this product.

Key words: butter, quality, humidity, salt, starch, nitrites, microbiological indicators.

\section{Контроль якості вершкового масла}

\author{
Т. А. Велесик ${ }^{1}$, Р. М. Сачук ${ }^{1}$, Б. В. Гутий ${ }^{2}$, А. С. Кушнірук ${ }^{1}$, В. О. Пепко ${ }^{3}$, О. А. Кацараба ${ }^{2}$ \\ ${ }^{1}$ Рівненський державний гуманітарний університет, м. Рівне, Украйна \\ ${ }^{2}$ Львівський національний університет ветеринарної медицини та біотехнологій імені С. 3. Гжиџького, м. Львів, \\ Україна \\ ${ }^{3}$ Тернопільська дослідна станція Інституту ветеринарної медицини НААН, м. Тернопіль, Україна
}


Найпоширенішою проблемою серед готових продуктів харчування є фальсифікація вершкового масла, яке замінюють на маргарин або рослинні спреди. Не залишають осторонь молоко та інші молокопродукти, які виробляють із молочної сировини. Виробництво та реалізація неякісної, фальсифікованої продукиії несе пряму загрозу здоров ю людини та впливає на конкурентне середовище серед виробників. В результаті проведених досліджень варто зазначити, щзо молочний сировинний ринок насичений не повною мірою, тому вдосконалення якісних показників виробництва вериків і переробки продуктів молока, а саме верикового масла, конкуренція за постачальників, мікробіологічні вдосконалення, а також вдосконалення установок і систем залишається актуальним. В ході аналізу досліджено деякі фізико-хімічні показники масла верикового, а саме: кислотність жирової фази, масова частка вологи та жиру. Показник кислотності був у межах норми, хоча й відрізнявся у всіх зразків: найменший виявили у зразка № 1 $\left(1,1^{\circ} \mathrm{K}\right)$, а найвищчи він був у зразка № 2 (1,6 $\left.{ }^{\circ} \mathrm{K}\right)$. Що стосується такого показника, як вміст кухонної солі та вміст жсиру й рН плазми, то масло солодковершкове “Селянське”, 72,6 \% ТМ “Своя лінія”, солодковершкове, 73,0 \% ТОВ “Еней”, “Полтавське”, 62,5 \% ТОВ “Техмолпром” - не відповідають вимогам ДСТУ 4399:2005. Масова частка жиру верикового масла торгівельних марок ПАТ “Дубномолоко” та “Приват-Фуд” - була меншою за зазначену на упаковці на 1,4\% та 2,6 \% відповідно, а торговельних марок “Своя лінія”, ТОВ “Еней” $і$ ТОВ “Техмолпром”, навпаки - на 18,0 \%, 18,4 \% та 12,5\% більшою. 3а результатами мікробіологічних досліджень встановлено, щуо кількість мезофільних аеробних та факультативно анаеробних мікроорганізмів, дріжджів, грибів і бактерій групи кишкової палички у досліджуваних зразках масла верикового всіх торгівельних марок не перевищує допустимих норм. Цей факт свідчить про відносну “чистоту” сировини, з якої було виготовлене верикове масло, а також про дотримання ветеринарних і санітарно-гігієнічних норм під час виробництва та зберігання вершкового масла. Підбиваючи підсумок проведених досліджень, необхідно зазначити, щуо незважаючи на виявлені фізико-хімічні недоліки всіх зразків верикового масла, перевагу необхідно віддати кисловериковому маслу “Селянське”, 73,0 \% ПАТ “Дубномолоко” та “Селянському” солодковериковому, 73,0 \% компаніі “Приват-Фуд”, оскільки в жодному із них не виявлено перевищення таких показників, як вміст жиру та рН плазми масла, щзо може свідчити про відсутність домішок рослинних жирів у даному продукті.

Ключові слова: масло верикове, якість, вологість, сіль, крохмаль, нітрити, мікробіологічні показники.

\section{Вступ}

Одним з основних та стратегічно важливих молочних продуктів, що виробляються нині на території України, є вершкове масло. Це висококалорійний та надзвичайно цінний продукт харчування, що має високий ступінь засвоюваності організмом людини. Масло вершкове багате на молочний жир, комплекс жиророзчинних вітамінів, містить в своєму складі білки, молочний цукор, мінеральні речовини, поліненасичені жирні кислоти. До його складу також входить лецитин, який, як відомо, є потужним антиоксидантом, а відтак запобігає розвитку низки захворювань у людини (Tsisaryk et al., 2016; Musiy \& Tsisaryk, 2016; Lyhovid et al., 2020).

Згідно з ДСТУ 4399:2005 “Масло вершкове” - це продукт, виготовлений лише з коров'ячого молока та продуктів його переробки.

Важливим моментом у підвищенні якості вершкового масла залишається здійснення виробничого та ринкового нагляду за продукцією, що охоплюється встановленими вимогами ветеринарно-санітарного та екологічного контролю.

Використання передового світового досвіду, стандартів, обладнання, дотримання санітарних норм, правил безпеки вершкового масла та продовольчої безпеки на всьому технологічному етапі “від лану до столу”, дасть можливість забезпечити споживача якісним, безпечним та корисним продуктом.

Аналіз останніх досліджень $і$ публікацій. Незважаючи на підвищений інтерес до проблеми якості та безпечності вершкового масла, ситуація у сфері харчових продуктів протягом усього життєвого циклу щороку ускладняється і стає загрозливішою. Встановлено харчову цінність молочного жиру, поліненасичених жирних кислот (лінолевої, ліноленової та арахідонової), які беруть участь у клітинному обміні речовин та мають антисклеротичні властивості. Цей продукт підвищує вміст в ньому фосфоліпідів, особливо лецитину, який переходить у масло разом з оболонками жирових кульок. В організмі людини леци- тин $\epsilon$ структурним компонентом мембран клітин, входить до складу мієлінової оболонки нервових клітин, є невід'ємним компонентом ферментів та належить до речовин, потреба в яких підвищується при нервових напруженнях. Крім того, з масла вершкового в організм людини надходять вітаміни $\mathrm{A}, \mathrm{E}, \mathrm{B}_{2}, \mathrm{C}$, Д, $\beta$-каротин та ін. В організмі людини в осінньозимовий період вміст вітамінів знижується. У процесі споживання масла людиною кількість вітамінів А і Д не зменшується, оскільки вони не руйнуються за температури нагрівання до $120{ }^{\circ} \mathrm{C}$ (Yakubchak et al., 2005; Rashevska, 2011).

Вершкове масло - найкращий тваринний жир, який виробляють із молочних вершків. Воно являє собою жироводну емульсію, дисперсійною фазою якої є жир, а у ньому - рівномірно розподілена волога i сухий знежирений молочний залишок, має оптимально збалансований комплекс жирних кислот, вітамінів, низьку температуру плавлення та легко засвоюється організмом людини (до 95 \%) (Kriu, 1979; Topnykova et al., 2013; Haidei et al., 2020; Fil, 2021).

Згідно з чинним ДСТУ 4399:2005 "Масло вершкове. Технічні умови”, що вступив у дію з 1 липня 2006 року, вершкове масло виготовляється тільки 3 коров'ячого молока або продуктів його переробки та призначене для безпосереднього вживання в їжу i кулінарних цілей. Вершкове масло виготовляють із доброякісних солодких вершків, одержаних із пастеризованого молока або з вершків, заквашених чистими культурами молочнокислих бактерій, які отриманні від здорової корови, молока незбираного згідно 3 ДСТУ 3662-97 (Derzhspozhyvstandart Ukrainy, 2018), закваски бактеріальної, як консерванти використовують сіль кухонну харчову, ретинол (вітамін А), воду, яка відповідає стандарту ДСТУ. При використанні сировини для масла не можна використовувати домішки рослинних масел (Kyrychenko et al., 2016). Також масло не повинно містити ніяких спеціальних харчових добавок. Стандартами заборонено у назві спредів і жирових сумішей вживати слово “масло” окремо або у словосполученнях (Shepelev \& Kozhukhova, 2001; 
Topnykova et al., 2013). Масло вершкове повинно мати специфічний притаманний йому смак, запах та пластичну консистенцію за температури $12 \pm 2{ }^{\circ} \mathrm{C}, 3$ вмістом молочного жиру не менше ніж: 61,5-72,4 \% вершкове масло бутербродне, 72,5-82,5 \% - вершкове масло селянське, 80,0-85,0 \% - вершкове масло екстра, що становить однорідну емульсію типу “вода в жирі” (Topnykova, 2013). Різноманітні вади смаку, запаху, кольору й консистенції вершкового масла виникають при використанні неякісної сировини, харчових добавок, не передбачених рецептурою, порушенні технології виготовлення, умов зберігання й реалізації готової продукції (Topnykova et al., 2013).

Крім традиційних методів досліджень, для доведення фактів фальсифікації молочної продукції, в тому числі вершкового масла, з використанням рослинних олій, існують методи дослідження зразків продукції у лабораторіях Держпродспоживслужби із використанням хроматографічних методів аналізу, зокрема методу газорідинної хроматографії. Під час досліджень таких зразків використовуються різні типи випробувань: аналіз нативних гліцеридів, аналіз жирнокислотного складу, аналіз стеринів.

Найчастіше для заміни молочного жиру виробники використовують гідровані рослинні жири або їх суміші з іншими жирами. При цьому самі фальсифікати поділяють на дві групи: в одному випадку вміст замінників молочного жиру складає понад $20 \%$, в іншому - частка останніх складає менше ніж $20 \%$.
Для ідентифікації наявності жирозамінників у кількості менше ніж 20 \% для молочної продукції, в тому числі вершкового масла, застосовують аналіз на вміст фітостеринів та холестерину. Такий метод дозволяє виявити наявність рослинної олії вже у кількості декількох відсотків - наявність на хроматограмі досліджуваного зразка піків фітостеринів однозначно свідчить про фальсифікацію молочної продукції.

Результати досліджень молока та молокопродуктів за допомогою методу виявлення вмісту фітостеринів та холестерину є підставою вважати продукцію традиційною чи фальсифікованою.

Тому комплексна оцінка кількісного вмісту і якісного складу харчових речовин, яка включає дослідження органолептичних показників, споживчих i технологічних характеристик вершкового масла, є дуже важливою для споживачів, оскільки вершкове масло є незмінним улюбленим продуктом українців.

Мета роботи - визначення якості та безпеки вершкового масла відомих торгових марок, які закуповували у продуктових магазинах м. Рівного.

\section{Матеріал і методи досліджень}

Об'єктом дослідження було 5 видів вершкового масла різних виробників, які закуповували у продуктових магазинах м. Рівного. Кожен вид масла був відібраний у кількості 3 одиниці з різних партій.

Таблиця 1

Перелік досліджуваних видів вершкового масла

\begin{tabular}{|c|c|c|c|}
\hline № & Найменування масла & НД & Виробник, адреса \\
\hline 1 & Кисловершкове “Селянське”, 73,0 \% & ДСТУ 4399:2005 & ПАТ “Дубномолоко”, м. Дубно, Рівненська область \\
\hline 2 & “Селянське” солодковершкове, 73,0 \% & ДСТУ 4399:2005 & $\begin{array}{l}\text { Компанія “Приват-Фуд”, м. Тульчин, Вінницька } \\
\text { область }\end{array}$ \\
\hline 3 & Солодковершкове “Селянське”, 72,6 \% & ДСТУ 4399:2005 & $\begin{array}{l}\text { ТМ “Своя лінія”, смт Слобожанське, Дніпропетров- } \\
\text { ська область }\end{array}$ \\
\hline 4 & Солодковершкове, 73,0 \% & ДСТУ 4399:2005 & ТОВ “Еней”, смт Романів, Житомирська область \\
\hline 5 & “Полтавське”, 62,5 \% & $\begin{array}{l}\text { ТУ У } 15.4-34465052- \\
001: 2006\end{array}$ & ТОВ “Техмолпром”, м. Гадяч, Полтавська область \\
\hline
\end{tabular}

Відбір та підготовку проб селянського вершкового масла до ветеринарно-санітарного аналізу здійснювали, керуючись ветеринарно-санітарними інструкціями, відповідно до ДСТУ 4399:2005 “Масло вершкове”.

Органолептичний аналіз вершкового масла здійснювали за такими показниками: консистенція та зовнішній вигляд, колір, запах і смак.

Фізико-хімічний аналіз якості вершкового масла здійснювали за такими показниками: кислотність, вміст кухонної солі, вміст жиру та рН плазми масла.

Визначення кислотності жирової фази вершкового масла здійснювалося за загальноприйнятою методикою - метод алкаліметрії (ДСТУ 4399:2005 ), визначення вмісту кухонної солі - метод з азотнокислим сріблом (ГОСТ 3627 - 81). Для визначення вмісту жиру використовували бутирометр (жиромір), показник вираховували за формулою: $\mathrm{X}=100-(\mathrm{B}+\mathrm{CB}), \mathrm{y}$ соленому: $\mathrm{X}=100-(\mathrm{B}+\mathrm{CB}+\mathrm{H})$, де $\mathrm{X}-$ вміст жиру, $\%$; СВ - вміст сухої знежиреної речовини, \%. Для топленого масла - 0,3\%, для вершкового соленого і несоленого - $1 \%$, для любительського - $2 \%$; Н вміст солі, \%; +В - вміст вологи в маслі, \%. рН плазми масла визначали за ДСТУ ISO 7238-2001 Масло вершкове. Потенціометричний метод визначення $\mathrm{pH}$ плазми (ISO 7238:1983, IDT).

Відбір проб і їхню підготовку до мікробіологічного аналізу здійснювали відповідно до ГОСТ 9225. Для цього від кожної пакувальної одиниці вершкового масла стерильним шпателем відбирали проби в кількості 20 г, включно $з$ поверхневим шаром масла.

Підготовку проб масла до мікробіологічного аналізу здійснювали таким чином: пробу масла у стерильному скляному посуді розтоплювали на водяній бані за температури $40 \ldots 45^{\circ} \mathrm{C}$ до утворення однорідної емульсії. Готували послідовні розведення масла в стерильних розчинах хлористого натрію та здійснювали посіви на поживні середовища. Дослідження проводилися на базі кафедри екології, географії та 
туризму Рівненського державного гуманітарного університету та у мікробіологічному секторі лабораторії 3 контролю якості, безпечності та реєстрації ветеринарних лікарських засобів і кормових добавок ТОВ “ДЕВIЕ” (м. Рівне) (Kyrychenko et al., 2016).

Посіви розведень робили на середовищі Сабуро, Ендо, Байрд-Паркера.

Статистичну обробку результатів виконано за загальноприйнятою методикою (Rokytskyi, 1973).

\section{Результати та їх обговорення}

Вітчизняне молочне скотарство насамперед займає досить відповідальну нішу у забезпеченні продовольчої безпеки держави. Молокопродукти є основою добробуту населення, а показники їх споживання (табл. 2) - одними з індикаторів стану забезпечення продовольчої безпеки.

Таблиця 2

Фактичне і нормативне споживання продуктів населенням України*

\begin{tabular}{|c|c|c|c|c|c|c|}
\hline \multirow{3}{*}{ Показник } & \multicolumn{4}{|c|}{ Рівень споживання на одну особу за рік, кг } & \multicolumn{2}{|c|}{ Потреба для населення України } \\
\hline & \multirow{2}{*}{$\begin{array}{c}\text { Норматив } \\
\text { MO3 }\end{array}$} & \multirow{2}{*}{$\begin{array}{c}\text { Факт } \\
\text { (2020 рік) }\end{array}$} & \multicolumn{2}{|c|}{ До нормативу } & \multirow{2}{*}{ Всього (млн тонн) } & \multirow[b]{2}{*}{ +/- до норми } \\
\hline & & & $+/-$ & $\%$ & & \\
\hline Молоко & 380,0 & 230,0 & $-150,0$ & 39,5 & 17,4 & $-7,7$ \\
\hline М'ясо в забійній вазі, всього & 80 & 59,0 & -28 & 65,0 & 3,6 & $-1,2$ \\
\hline в т. ч. яловичина & 31,3 & 9,7 & $-22,3$ & 30,3 & 1,4 & $-0,9$ \\
\hline свинина & 30 & 17,6 & $-12,4$ & 58,7 & 1,3 & $-0,5$ \\
\hline птиця & 16,7 & 23,6 & 6,6 & 138,8 & 0,7 & 0,3 \\
\hline інші & 2 & 1,1 & $-0,9$ & 55,0 & 0,1 & $-0,1$ \\
\hline
\end{tabular}

"Джерело: Державна служба статистики України, Молочна консалтингова фірма, CLAL

Аналіз даних табл. 2 дає змогу зробити висновок, що населення України не має достатнього харчування, відповідно до потреб організму, майже за всіма видами продукції тваринництва.

Потрібно врахувати і те, що молокопереробна галузь України характеризується спадом виробництва, значним зниженням асортименту продукції, скрутним фінансово-економічним станом більшості підпри- ємств, високим коефіцієнтом зносу основних виробничих фондів і відсутністю інтегрування виробництва, переробки та реалізації продукції.

Наприклад, у 2010 році збитковість виробництва молока була на рівні 3,7 \%. За десять років ситуація на ринку значно не змінилася, однак виробництво молока продемонструвало рентабельність на рівні $26,9 \%$ (рис. 1 ).

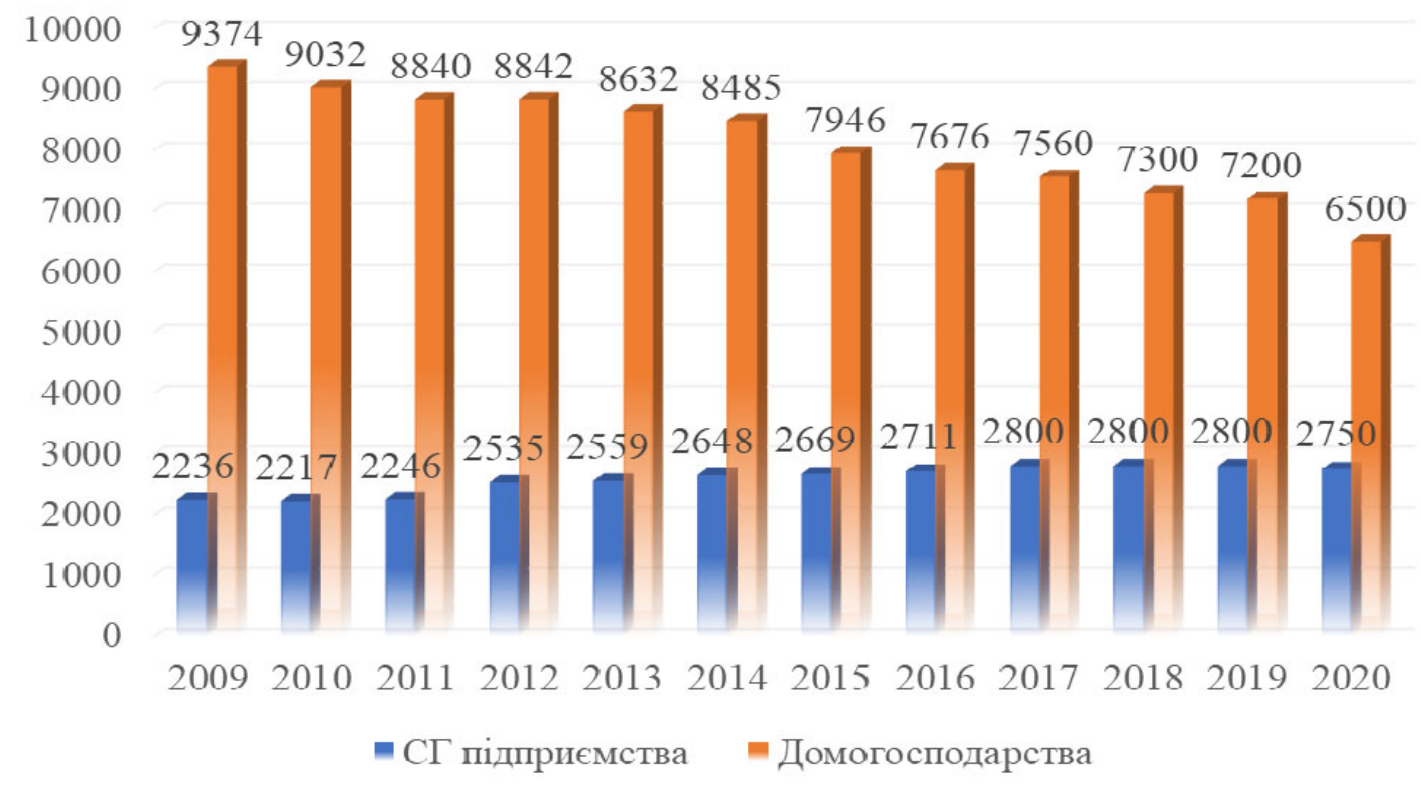

Рис. 1. Виробництво молока, тис. т

Враховуючи нинішню ситуацію в Україні, аналізуючи матеріали надані НДІ "Украгропромпродуктивність" та спираючись на дані Державної служби статистики України (форма № 24, місячна), встановлено, що станом на 1 серпня 2021 року продовжується стійка тенденція до зменшення поголів'я великої рогатої худоби. В усіх категоріях господарств воно скоротилося на 218,5 тис. голів, у тому числі в сільськогосподарських підприємствах - на 12,4 тис., у господарствах населення - на 206,1 тис. голів. Корів у всіх категоріях господарств зменшилося на 104,9 тис. голів, у тому числі в сільськогосподарських підприємствах - на 0,1 тис., у господарствах населення - на 104,8 тис. голів. 
Станом на 1 серпня 2021 року, порівняно з аналогічним періодом минулого року, в господарствах усіх категорій не вдалося стабілізувати ситуацію з виробництва молока. Даний показник зменшився на 333,2 тис. т $(6,0 \%)$, у тому числі в сільськогосподарських підприємствах - на 18,2 тис. т (1,1\%), в господарствах населення - на 315,0 тис. $(8,1 \%)$.

Найбільшою проблемою молочного сектору стала втрата російського ринку, куди постачалося близько 70-80 \% усього молочного експорту. Найбільша частка у виробництві належить домогосподарствам, що відкриває потенційні можливості для кооперації, як це відбувається у деяких європейських країнах. Проте в Україні домогосподарства виробляють продукцію низької якості. Майже все молоко, що виробляється домогосподарствами, є 3-го класу або нижче. У 2020 році аграрні підприємства збільшили свою частку у виробництві молока до 20 \% (2,1 млн т), що призвело до збільшення частки молока екстра класу, 13 \% якого було перероблено.

За даними Державної служби статистики, у січнілипні 2021 року в Україні виробили 41,7 тис. тонн вершкового масла жирністю до 85 \%. Це на 20,6 \% менше, ніж за аналогічний період минулого року. Зокрема, у липні обсяг виробництва вершкового мас- ла склав 6,3 тис. тонн, що на 18,9 \% менше порівняно 3 аналогічним періодом минулого року.

Незважаючи на скорочення виробництва молока та продуктів його переробки в останні роки, в Україні постає питання вдосконалення якісних показників виробництва вершків і переробки продуктів молока, а саме вершкового масла, конкуренція за постачальників, мікробіологічні вдосконалення а також вдосконалення установок і систем.

При досліджені якості та безпеки продукції, яку закуповували у продуктових магазинах м. Рівного, на першому етапі роботи проводилося визначення правильності ідентифікації досліджуваних зразків вершкового масла. Важливим засобом ідентифікації масла $\epsilon$ маркування, яке містить інформацію, придатну для цілей ідентифікації. Вивчення стану маркування товарів проведено згідно Закону України "Про основні принципи та вимоги до безпечності та якості харчових продуктів" та Закону України “Про інформацію для споживачів щодо харчових продуктів” (введення в дію від 06.08.2019 р.) (Zakon Ukrainy, 2019), табл. 3. Аналіз представлених даних ідентифікації досліджуваних зразків вершкового масла свідчить, що маркування нанесене правильно, в повному обсязі, без порушень.

\section{Таблиця 3}

Перевірка маркування досліджуваних зразків вершкового масла

\begin{tabular}{|c|c|c|c|c|c|}
\hline \multirow{2}{*}{ Показник } & \multicolumn{5}{|c|}{ Зразок } \\
\hline & 1 & 2 & 3 & 4 & 5 \\
\hline Назва харчового продукту & + & + & + & + & + \\
\hline Склад харчового продукту & + & + & + & + & + \\
\hline Кількість харчового продукту & + & + & + & + & + \\
\hline Мінімальний термін придатності або дата “вжити до” & + & + & + & + & + \\
\hline Будь-які особливі умови зберігання та/або умови використання & + & + & + & + & + \\
\hline $\begin{array}{l}\text { Найменування та місцезнаходження оператора ринку харчових } \\
\text { продуктів, відповідального за інформацію про харчовий продукт, } \\
\text { а для імпортованих харчових продуктів - найменування та місце- } \\
\text { знаходження імпортера }\end{array}$ & + & + & + & + & + \\
\hline Країна походження або місце походження & + & + & + & + & + \\
\hline Інформація про ГМО в складі харчового продукту & + & + & + & + & + \\
\hline Інформація про поживну цінність харчового продукту & + & + & + & + & + \\
\hline
\end{tabular}

Крім того, було проведено ідентифікацію масла, яка включала у себе аналіз документів на товар. Для цього замовнику експертизи було надано такі документи: контракт, рахунок-фактуру, сертифікат відповідності. За результатами ідентифікації, шляхом порівняння нормативних та фактичних ознак, визначено відповідність даних партій масла сертифікатам якості та чинному стандарту на цю продукцію.

При зважуванні та порівнянні маси нетто встановили, що у зразків № 1, 2, 3 та 4 приблизно однакова маса $-200 \pm 3$ г та зразка № $5-160 \pm 3$ г.

Наступним етапом роботи стала органолептична оцінка вершкового масла. Визначали: якість упаковки, зовнішній вигляд, колір, консистенцію і якість обробки, запах та смак (табл. 4).
За результатами експертизи фізико-хімічних показників якості вершкового масла можна побачити, що масло вершкове виробництва ПАТ “Дубномолоко” та компанії "Приват-Фуд” відповідає вимогам стандарту ДСТУ 4399:2005 за такими показниками: кислотність, вміст кухонної солі та жиру. Показник кислотності був у межах норми, хоча й відрізнявся у всіх зразків: найменший виявили у зразка № $1\left(1,1^{\circ} \mathrm{K}\right)$ і найвищим він був у зразка № 2 (1,6 $\left.{ }^{\circ} \mathrm{K}\right)$. Що стосується вмісту кухонної солі, вмісту жиру та рН плазми, то масла Солодковершкове “Селянське”, 72,6 \% ТМ “Своя лінія”, Солодковершкове, 73,0 \% ТОВ “Еней”, “Полтавське”, 62,5 \% ТОВ “Техмолпром” - не відповідають вимогам ДСТУ 4399:2005 (табл. 5). 
Таблиця 4

Органолептична характеристика досліджуваних зразків вершкового масла

\begin{tabular}{|c|c|c|}
\hline $\begin{array}{c}\text { Найменування } \\
\text { вершкового масла }\end{array}$ & Консистенція та зовнішній вигляд & Колір, смак і запах \\
\hline $\begin{array}{l}\text { Кисловершкове } \\
\text { "Селянське", } \\
73,0 \%\end{array}$ & $\begin{array}{l}\text { Однорідна, пластична, щільна, поверхня, } \\
\text { на розрізі слабкоблискуча, має крапель- } \\
\text { ки вологи. Масло з холодильника тверде }\end{array}$ & $\begin{array}{l}\text { Колір світло-жовтий, однорідний по всій масі, без сто- } \\
\text { роннього присмаку і запаху, характерний для вершк-- } \\
\text { вого масла, } 3 \text { присмаком пастеризованих вершків. } \\
\text { При споживанні масла у ротовій порожнині не залиша- } \\
\text { ється відчуття жирного нальоту }\end{array}$ \\
\hline $\begin{array}{l}\text { “Селянське” } \\
\text { солодковершкове, } \\
73,0 \%\end{array}$ & $\begin{array}{l}\text { Однорідна, ніжна. Масло з холодильни- } \\
\text { ка тверде }\end{array}$ & $\begin{array}{l}\text { Колір білий, однорідний по всій масі, без стороннього } \\
\text { присмаку і запаху, характерний для вершкового масла, } \\
3 \text { присмаком пастеризованих вершків. } \\
\text { При споживанні масла у ротовій порожнині не залиша- } \\
\text { ється відчуття жиру }\end{array}$ \\
\hline $\begin{array}{l}\text { Солодковершкове } \\
\text { "Селянське", } \\
72,6 \%\end{array}$ & $\begin{array}{l}\text { Однорідна пластична щільна поверхня } \\
\text { масла, на розрізі слабо блискуча і суха } \\
\text { на вигляд або } 3 \text { наявністю поодиноких } \\
\text { дрібних крапель вологи. Масло } 3 \text { холо- } \\
\text { дильника тверде }\end{array}$ & $\begin{array}{l}\text { Колір світло-жовтий, однорідний по всій товщі, без } \\
\text { стороннього присмаку і запаху, характерний для верш- } \\
\text { кового масла. } \\
\text { При споживанні масла у ротовій порожнині не залиша- } \\
\text { ється відчуття жирного нальоту }\end{array}$ \\
\hline $\begin{array}{l}\text { Солодковершкове, } \\
73,0 \%\end{array}$ & $\begin{array}{l}\text { Однорідна, ніжна, у міру щільна. Масло } \\
\text { з холодильника тверде }\end{array}$ & \multirow{2}{*}{$\begin{array}{l}\text { Колір світло-жовтий, } \\
\text { однорідний по всій товщі Присмак сухого молока. }\end{array}$} \\
\hline $\begin{array}{l}\text { "Полтавське", } \\
62,5 \%\end{array}$ & $\begin{array}{l}\text { Однорідна, дещо рідкувата, без шматоч- } \\
\text { ків персика, з наявністю газоутворення. } \\
\text { Масло з холодильника м'яке }\end{array}$ & \\
\hline $\begin{array}{l}\text { Норма за ДСТУ } \\
4399: 2005\end{array}$ & $\begin{array}{l}\text { Для Вологодського масла - однорідна, } \\
\text { пластична, щільна. Поверхня масла на } \\
\text { розрізі блискуча, суха на вигляд. Для } \\
\text { несолоного, Любительского, Селянсько- } \\
\text { го масла - однорідна пластична щільна. } \\
\text { Поверхня масла, на розрізі слабо блис- } \\
\text { куча і суха на вигляд або з наявністю } \\
\text { одиночних мілких крапель вологи. Для } \\
\text { топленого масла - зерниста, м'яка в } \\
\text { розтопленому вигляді, топлене масло } \\
\text { прозоре без осаду }\end{array}$ & $\begin{array}{l}\text { Для Вологодського масла чистий, добре виражений } \\
\text { смак і запах вершків без сторонніх присмаків і запахів. } \\
\text { Для несоленого, соленого, Любительского, Селянсько- } \\
\text { го масла - чистий без сторонніх присмаків і запахів, } \\
\text { характерний для вершкового масла, з присмаком пасте- } \\
\text { ризованих вершків або без нього - для солодко верш- } \\
\text { кового, з кисломолочним смаком і запахом - для кис- } \\
\text { ловершкового, помірно соленим смаком для солоного } \\
\text { масла. Для топленого масла - специфічний смак і запах } \\
\text { витопленого молочного жиру без сторонніх присмаків і } \\
\text { запахів. Для вершкового масла - від білого до жовтого, } \\
\text { однорідний по всій масі. Для топленого масла - від } \\
\text { світло-жовтого до жовтого, однорідний по всій масі }\end{array}$ \\
\hline
\end{tabular}

Табл. 5

Результати фізико-хімічних досліджень досліджуваних зразків вершкового масла $(\mathrm{M} \pm \mathrm{m}, \mathrm{n}=3)$

\begin{tabular}{ccccc}
\hline Номер зразка & Кислотність & Вміст кухонної солі, \% & Вміст жиру, \% & рН плазми масла \\
\hline 1 & $1,1 \pm 0,41$ & $0,94 \pm 0,97$ & $72,0 \pm 0,21$ & $6,14 \pm 0,11$ \\
2 & $1,6 \pm 0,03$ & $1,0 \pm 0,47$ & $71,1 \pm 0,20$ & $6,15 \pm 0,21$ \\
3 & $1,4 \pm 0,09$ & $0,86 \pm 0,12$ & $88,5 \pm 0,09$ & $8,8 \pm 0,09$ \\
4 & $1,2 \pm 0,11$ & $1,15 \pm 0,14$ & $89,5 \pm 0,01$ & $8,9 \pm 0,11$ \\
5 & $1,5 \pm 0,07$ & $0,99 \pm 0,77$ & $71,4 \pm 0,04$ & $9,4 \pm 0,14$ \\
\hline
\end{tabular}

Масова частка жиру вершкового масла торгівельних марок ПАТ “Дубномолоко” та “Приват-Фуд” була меншою за зазначену на упаковці на 1,4 \% та 2,6 \%, а торгівельних марок “Своя лінія”, ТОВ “Еней” і ТОВ “Техмолпром”, навпаки, на 18,0 \%; 18,4 \% та 12,5 \% вище.

Аналізуючи дані табл. 5, можна стверджувати, що за фізико-хімічними показниками спостерігали відхилення від вимог стандартів ДСТУ 4399:2005 "Масло вершкове" у всіх досліджуваних зразках.

Причиною цього може бути недотримання умов зберігання, транспортування продукту, низька якість молочної сировини, фальсифікація та високий рівень фізичного зносу обладнання молокопереробних підприємств.
Результати мікробіологічних досліджень сформовано у вигляді табл. 6.

За результатами мікробіологічних досліджень встановлено, що кількість мезофільних аеробних та факультативно анаеробних мікроорганізмів, дріжджів, грибів і бактерій групи кишкової палички у досліджуваних зразках масла вершкового всіх торгівельних марок не перевищує допустимих норм. Цей факт свідчить про відносну “чистоту” сировини, з якої було виготовлене вершкове масло, а також про дотримання ветеринарних і санітарно-гігієнічних норм під час виробництва та зберігання вершкового масла.

Підбиваючи підсумок проведених досліджень, зазначимо, що незважаючи на виявлені фізико-хімічні недоліки всіх зразків вершкового масла, перевагу необхідно надати кисловершковому маслу "Селянсь- 
ке”, 73,0 \% ПАТ “Дубномолоко” та “Селянське” солодковершковому, 73,0 \% компанії “Приват-Фуд”, оскільки у жодному 3 них не виявлено перевищення таких показників, як вміст жиру та рН плазми масла. Це може свідчити про відсутність домішок рослинних жирів у даному продукті.

\section{Таблиця 6}

Результати мікробіологічних досліджень досліджуваних зразків вершкового масла

\begin{tabular}{cccccc}
\hline \multirow{2}{*}{$\begin{array}{c}\text { Номер } \\
\text { зразка }\end{array}$} & $\begin{array}{c}\text { Кількість МАФаМ, } \\
\text { не більше ніж КУО } \\
\text { в 1 г }\end{array}$ & $\begin{array}{c}\text { Кількість дріжджів, } \\
\text { грибів, КУО в 1 г, не } \\
\text { більше ніж }\end{array}$ & $\begin{array}{c}\text { Кількість МА- } \\
\text { ФаМ, не більше } \\
\text { ніж КУО в 1г }\end{array}$ & $\begin{array}{c}\text { Кількість дріжджів, } \\
\text { грибів, КУО в 1 г, не } \\
\text { більше ніж }\end{array}$ & $\begin{array}{c}\text { Бактерії групи } \\
\text { кишової палич- } \\
\text { ки КУО в 1 г }\end{array}$ \\
\hline 1 & & & $1,9 \pm 0,03 \times 10^{4}$ & $3,1 \pm 0,01 \times 10^{4}$ & Не виявлено \\
2 & & 100 в сумі & $2,1 \pm 0,01 \times 10^{4}$ & $2,9 \pm 0,02 \times 10^{4}$ & Не виявлено \\
3 & $1,0 \times 10^{5}$ & & $2,9 \pm 0,02 \times 10^{4}$ & $1,8 \pm 0,03 \times 10^{4}$ & Не виявлено \\
4 & & & $1,0 \pm 0,01 \times 10^{5}$ & $1,9 \pm 0,01 \times 10^{4}$ & Не виявлено \\
5 & & & & & \\
\hline
\end{tabular}

\section{Висновки}

1. В результаті визначення правильності ідентифікації встановлено, що маркування досліджуваного вершкового масла торгових марок ПАТ “Дубномолоко”, “Приват-Фуд”, “Своя лінія”, ТОВ “Еней” і ТОВ “Техмолпром” виконано правильно. Необхідна інформація про харчовий продукт нанесена на пакування в повній мірі.

2. Встановлено, що показник кислотності був у межах норми, хоча й відрізнявся у всіх зразків: найменший виявили у зразка № $1\left(1,1^{\circ} \mathrm{K}\right)$ і найвищим він був у зразка № $2\left(1,6^{\circ} \mathrm{K}\right)$. Що стосується масла Солодковершкове, 73,0 \% ТОВ “Еней”, то за вмістом кухонної солі, за вмістом жиру та $\mathrm{pH}$ плазми масла Сoлодковершкове “Селянське”, 72,6 \% ТМ “Своя лінія”, Солодковершкове, 73,0 \% ТОВ “Еней”, "Полтавське”, 62,5 \% ТОВ “Техмолпром” не відповідають вимогам ДСТУ 4399:2005.

3. Масова частка жиру вершкового масла торгівельних марок ПАТ “Дубномолоко” та "Приват-Фуд” була меншою за зазначену на упаковці на 1,4 \% та 2,6 \%, а торгівельних марок “Своя лінія”, ТОВ “Еней” i ТОВ “Техмолпром”, навпаки - на 18,0 \%, 18,4 \% та $12,5 \%$ більшою.

4. За результатами мікробіологічних досліджень встановлено, що вершкове масло всіх досліджуваних торгівельних марок відповідає вимогам чинних нормативних документів.

Перспективи подальших досліджень. Перспективи подальших досліджень варто зосередити на вдосконаленні технологічного процесу виробництва продукції, а саме - визначенні жирнокислотного складу вершкового масла 3 метою встановлення відповідності стандартам ДСТУ 4399:2005.

\section{References}

DSTU 4399:2005 (2006). Maslo vershkove. Tekhnichni umovy. K.: Derzhspozhyvstandart Ukrainy (in Ukrainian).

Fil, M. (2021). Innovative approach to technology egg omelet. Scientific Messenger of LNU of Veterinary Medicine and Biotechnologies. Series: Food Technologies, 23(95), 7882. doi: $10.32718 /$ nvlvet-f9513.
Haidei, O., Shuliak, S., Oleksiienko, I., Kyivska, G., \& Krushelnytska, O. (2020). Monitoring of gluten in dairy products. Scientific Messenger of LNU of Veterinary Medicine and Biotechnologies. Series: Food Technologies, 22(94), 8-12. doi: 10.32718/nvlvet-f9402.

Ivchenko, V. M., Soloshonok, A. L., \& Mamochka, A. Iu. (2021). Zvedeni dani pro stan tvarynnytstva Ukrainy. [Summary data on the state of animal husbandry in Ukraine]. K.: NDI "Ukrahropromproduktyvnist" (in Ukrainian).

Kasianchuk, V. V. (2000). Cuchasni mizhnarodni vymohy shchodo bezpeky kharchovykh produktiv. [Modern international requirements for food safety]. Veterynarna medytsyna Ukrainy, 5, 18-19 (in Ukrainian).

Kriu, Zh. (1979). Byokhymyia. Medytsynskye y byolohycheskye aspekty. [Biochemistry. Medical and biological aspects]. M.: Medytsyna (in Russian).

Kunyk, O. M., Nahrebelna, A. S., \& Saribiekova, D. H. (2020). Tekhnolohichna ekspertyza vershkovoho masla. [Technological examination of butter]. Herald of Khmelnytskyi national university, 6(291), 180-184 (in Ukrainian).

Kyrychenko, V. A., Kot, S. P., Kalynychenko, H. I., \& Barkar, Ye. V. (2016). Veterynarno-sanitarna ekspertyza moloka ta molochnykh produktiv. [Veterinary and sanitary examination of milk and dairy products] (in Ukrainian).

Lyhovid, D., Slyvka, N., Bilyk, O., \& Skulska, I. (2020). Improvement of technology of melt butter with turmeric. Scientific Messenger of LNU of Veterinary Medicine and Biotechnologies. Series: Food Technologies, 22(94), 66-70. doi: 10.32718/nvlvet-f9413.

Moloko-syrovyna koroviache (2018). Tekhnichni umovy. Slovnyk terminiv DSTU 3662:2018 [Chynnyi vid 2019.01.01.]. K.: Derzhspozhyvstandart Ukrainy (in Ukrainian).

Musiy, L., \& Tsisaryk, O. (2016). Study of the cream fermentation and physical maturation in the springsummer period under the production of butter with probiotic properties. Scientific Messenger of LNU of Veterinary Medicine and Biotechnologies. Series: Food Technologies, 18(2), 56-62. doi: 10.15421/nvlvet6811.

Rashevska, T. O. (2011). Tekhnolohiia moloka i molochnykh produktiv: pidruchnyk dlia studentiv spetsialnosti 7.091709 "Tekhnolohiia zberihannia, konser- 
vuvannia ta pererobky moloka". [Technology of milk and dairy products: a textbook for students majoring in 7.091709 "Technology of storage, canning and processing of milk"]. Kyiv (in Ukrainian).

Rokytskyi, P. F. (1973). Byolohycheskaia statystyka. [Biological statistics] Minsk: Vysheishaia shkola (in Russian).

Shepelev, A. F., \& Kozhukhova, O. Y. (2001). Tovarovedenye y ekspertyza moloka y molochnykh produktov: uchebnoe posobye. [Commodity research and examination of milk and dairy products: a tutorial.]. Rostov n/D.: Yzdatelskyi tsentr "MarT" (in Russian).

Topnykova, E. V. (2013). Proizvodstvo moloka i molochnykh produktov v Ukraine za 11 mesiatsev 2012 hoda [Production of milk and dairy products in Ukraine for 11 months 2012]. Molokopererabotka. Analitika, 1(88), 15-28 (in Ukrainian).

Topnykova, E. V., Horshkova, E. Y., \& Merkulova, M. Y. (2013). Yssledovanyia zhyrnokyslotnoho sostava slyvochnoho masla [Studies of the fatty acid composition of butter]. Syrodelye y maslodelye. 3, 47-49 (in Russian).

Tsisaryk, O. Y., Musiy, L. Y., \& Shereshkov, V. (2016). Development of technology of dairy butter is withnuthoney filler. Scientific Messenger of LNU of
Veterinary Medicine and Biotechnologies. Series: Food Technologies, 18(1), 155-160. URL: https://nvlvet.com.ua/index.php/food/article/view/3237.

Tsisaryk, O. Y., Musiy, L. Y., \& Shereshkova, O. (2016). Resistance to oxidation butter with nut-honey filler. Scientific Messenger of LNU of Veterinary Medicine and Biotechnologies. Series: Food Technologies, 18(1), 148-154. URL: https://nvlvet.com.ua/index. $\mathrm{php} /$ food/article/view/3236.

Yakubchak, O. M., Khomenko, V. I., Melnychuk, S. D., \& Kovbasenko, V. M. (2005). Veterynarno-sanitarna ekspertyza z osnovamy tekhnolohii i standartyzatsii produktiv tvarynnytstva. [Veterinary and sanitary examination with the basics of technology and standardization of livestock products]. K.: Bioprom (in Ukrainian).

Zakon Ukrainy (2019). Pro informatsiiu dlia spozhyvachiv shchodo kharchovykh produktiv. Vidomosti Verkhovnoi Rady (VVR) URL: https://zakon.rada.gov.ua/laws/show/2639-19\#Text (in Ukrainian). 